\title{
操舵性能の物理特性モデリングを活用した伝達系要素設計に関する研究*
}

（第 1 報）

中野 史郎 ${ }^{* 1}$, 吉元 浩司 ${ }^{* 2}$, 木村 秀司 ${ }^{* 2}$, 葉山 良平 ${ }^{* 2}$

\section{Strategy for Transfer Elemental Designing, Employing Physical Characteristic Modeling of Steering Maneuver (First Report)}

\author{
Shirou NAKANO*1, Hiroshi YOSHIMOTO, Shuuji KIMURA and Ryouhei HAYAMA \\ ${ }^{* 1}$ JTEKT CORPORATION. Research \& Development Center \\ Toichi-cho 333, Kashihara-city, Nara, 634-8555 Japan
}

Improvement of value-added steering maneuvering is required more than ever, for wider range of passenger vehicles. Steering is one of the key systems to achieve better vehicle maneuvering. Sensory evaluation of "steering feeling" can hold contingency designing strategy. But, uncertainty of human factors should be taken into account for estimation of physical quantities. Some methods that specify relation between "steering feelings" and performances of vehicle dynamics have been proposed but not practical for actual design of steering components. In this paper, the theoretical method with detailed steering model that specifies quantitative performances and physical quantities for steering components is proposed.

Key Words : Human Interface, Optimal Design, Modeling, Man Machine System, Frequency Response Function

\section{1. はじめに}

自動車技術の進歩と共に自動車の性能はもれなく大きく向上した．各部品の故障率や経年劣化の低減だけで なく，実用上の使い易さなど付加価值の向上も求められている.

ステアリングも運転者の操舵入力に対する反力の変化や車両旋回の応答性など，操作性向上のための重要な 要素部品である ${ }^{(1)}$. 車両におけるステアリングの性能評価は, 一般の操作性評価と同様, 感性の影響を受け や寸い官能評価のため，定量的に扱うことが難しい。これに対し，これまで様々な分野で操作性を定量化し， 設計に活用する試みが数多く続けられてきた. 例えば, マスタ・スレーブ型遠隔操縦システムの分野においては, 操作性を定量的に評価し，制御系設計の指針を示したものがある(2).しかし，自動車の操舵感評価においては 実現手段としての要素部品特性との関係が定量的に明らかにされた例はない.

そこで, 操舵性能に関する物理特性を厳密に表現したステアリングシステムのモデルを導入した. 本稿では, 本モデルを用いてステアリングシステムの伝達特性を解析した。 また，伝達特性に関わる物理量を，部品ごとの 設計目標值として決定する手法について述べる.

\section{2. ステアリング性能}

ステアリングシステムに要求される性能の例を表 1 に示す.これらの性能の向上を理論的に行うためには,

* 原稿受付 2010 年 12 月 26 日

*1 正員, (株) ジェイテクト（预634-8555 奈良県橿原市十市町 333）

*2 (株) ジェイテクト（テ634-8555＼cjkstart奈良県橿原市十市町 333）

E-mail: Shirou_nakano@jtekt.co.jp 
Table 1 Performance demanded for steering system

\begin{tabular}{c|l}
\hline \multicolumn{1}{c|}{ Requirement } & \multicolumn{1}{c}{ Performance } \\
\hline \multirow{2}{*}{$\begin{array}{l}\text { (i) Function of steering } \\
\text { and assist torque }\end{array}$} & $\begin{array}{l}\text { Powering effort, } \\
\text { Force deflection } \\
\text { Free play of steering wheel } \\
\text { Noise, Vibration etc. }\end{array}$ \\
\hline \multirow{3}{*}{ (ii) Strength, Endurance } & $\begin{array}{l}\text { Steering wheel torque } \\
\text { Force on the road wheels } \\
\text { Vibrational input }\end{array}$ \\
\hline & $\begin{array}{l}\text { Smoothness of torque } \\
\text { Feeling of inertia, viscosity, } \\
\text { fiii) Steering feeling }\end{array}$ \\
\hline
\end{tabular}

定量的目標值をシステム設計段階で設定しなければならない。さらにそれを実現する要素部品ごとの性能の 目標值を物理量として明確にすることが必要である.

操舵機能, アシスト機能（表 1-i ）はパワーステアリングのアシスト量およびその追従性などで評価される. また, 強度, 而久性（表 1-ii ）に関しては, 振動や衝撃などを含む負荷が与えられた後の機能維持が求められる. これらは明確な数值基準により評価できるため, 実際の製品開発においても効率的に性能向上が図られてきた. 一方, 操舵感（表 1-iii）については, 評価専門の技能者に頼った官能評価結果とそれに向けての適合評価など での性能向上が図られている.

\section{3. 操舵感向上の取組みにおける課題}

\section{$3 \cdot 1$ 官能評価}

操舵感はステアリングを操作する際の操舵力の変化特性や車両挙動との関係を感覚的に評価した指標である. 表 2 に評価用語（1）の例を示し，これらに対してパイロットレーティング手法 ${ }^{(3)}$ を適用した評価例を表 3 に 示寸．表 3 より，車両 $\mathrm{C}$ の評価において慣性感の評価点が低いことがわかる．しかしこの指標だけでは，「どの 要素部品の特性を, どの程度改善するか」が定量的に示されておらず，官能評価の結果を理論的に活用すること はできない。

Table 2 Expressions for steering feeling

\begin{tabular}{l|l}
\hline \multicolumn{1}{c}{ Phenomena, Function } & Sensory evaluation term \\
\hline $\begin{array}{l}\text { S. A. T. (self aligning torque) } \\
\text { transformation to steering } \\
\text { wheel }\end{array}$ & $\begin{array}{l}\text { On-center feel } \\
\text { Build-up feel } \\
\text { Direct feel } \\
\text { etc. }\end{array}$ \\
\hline No sticky or dragged feeling & $\begin{array}{l}\text { Smooth without stick } \\
\text { Low-friction } \\
\text { etc. }\end{array}$ \\
\hline $\begin{array}{l}\text { Low-inertia feel } \\
\text { Mteering. }\end{array}$ & $\begin{array}{l}\text { High rigidity feel } \\
\text { Wall effect } \\
\text { etc. }\end{array}$ \\
\hline $\begin{array}{l}\text { Stable on-center or at keeping } \\
\text { angle }\end{array}$ & $\begin{array}{l}\text { Stability } \\
\text { Steadiness } \\
\text { Solid feel } \\
\text { etc. }\end{array}$ \\
\hline $\begin{array}{l}\text { S. A. T. transformation } \\
\text { without variation or vibration }\end{array}$ & $\begin{array}{l}\text { Smoothness } \\
\text { Continuous } \\
\text { Silky } \\
\text { etc. }\end{array}$ \\
\hline Assist torque characteristics & $\begin{array}{l}\text { Easy driving } \\
\text { Preferred/ not preferred } \\
\text { etc. }\end{array}$ \\
\hline
\end{tabular}

Table 3 Example of pilot rating of steering system

\begin{tabular}{c|c|c|c}
\hline \hline $\begin{array}{c}\text { Evaluation } \\
\text { items }\end{array}$ & Vehicle A & Vehicle B & Vehicle C \\
\hline Returnability & 6 & 5.5 & 6 \\
\hline $\begin{array}{c}\text { Low-friction } \\
\text { feel }\end{array}$ & 6 & 6 & 5.5 \\
\hline Low-inertia feel & 6 & 6 & 4 \\
\hline On-center feel & 6 & 6 & 5.5 \\
\hline Response & 6 & 6 & 6 \\
\hline
\end{tabular}




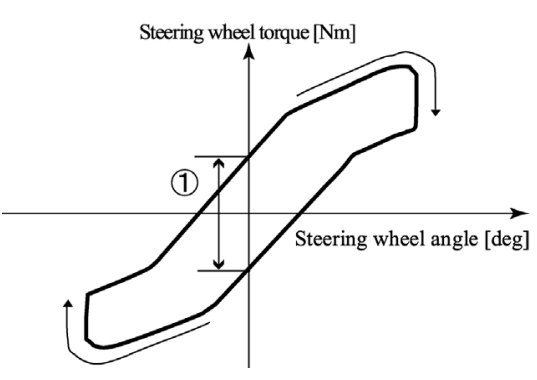

Fig.1 Correlation in steering reaction

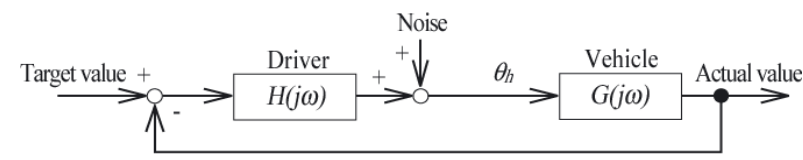

(a) Driver-vehicle model

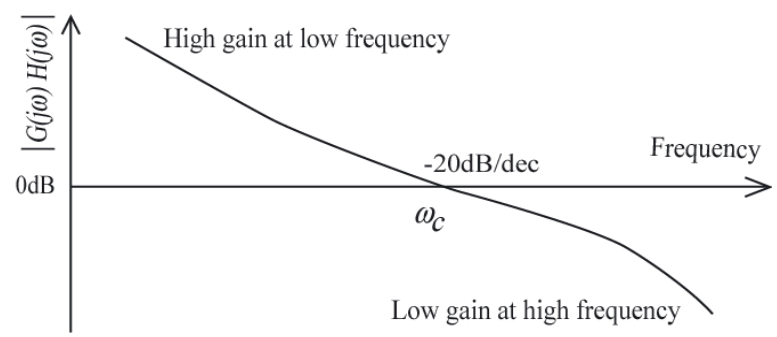

(b) Open-loop gain

Fig.2 Dynamic interaction of driver and vehicle

\section{$3 \cdot 2$ 官能評価の定量化}

この例から，前章に述べた専門技能者の評価によるフィードバックが，物理量として定量化されずに行われて いる課題がある．また，官能評価は評価者の技能に依存し，人の感性の違いによって評価点が異なることを考慮 する必要がある，このため，多変量解析手法により，評価結果と車両特性を表す物理量との相関関係を求める ことが提案されている(4)(5). 以下に「ステアリングホィールの手応え感」の解析例を示す.

車速 20〜140 km/h において,最大横加速度が 1.96 2.94 m/s 2 となるスラローム走行を行う.ステアリング ホィール角が $0 \mathrm{deg}$ 時のステアリングホィールトルクの值（図 1-(1)）が $0.1 \sim 0.2 \mathrm{Nm}$ の範囲に収まる場合, 手応え感に対する評価が高くなる ${ }^{(5)}$. このような評価手法を用いることで, 目標の操舵感を達成するための車両 特性の目標指針が示される．また，車両特性の内，操舵性能に関しても伝達系モデル化の基本技術によりそれら の目標特性指針を求めることは可能となっている ${ }^{(6)}$. しかし，直進状態からの切り出しにおける操舵感について は，運転時間の多くを占めているにもかかわらず，モデル化及び解析が十分ではない状況である．そのため, 本稿では, 特に切り出しにおける目標操舵特性を実現するための, 各要素部品の細部仕様定量化が可能となる, 十分に正確なモデル化を行う.

\section{4. ステアリング系伝達特性と操舵性能の解析}

\section{$4 \cdot 1$ ステアリングの目標特性導出}

図 2(a)に運転者を含む操舵系のフィードバック制御ループを示す. 運転者は交通環境などから操舵角を決定し, ステアリングシステムに入力を加える. その入力はシャシー・タイヤに伝達され, 路面反力により車両に旋回運動 が生じる。ここで, シャシーは操舵特性に影響を与えるサスペンションなどの車両構成要素を指す.この時, タイヤに発生した力がステアリングを通じて運転者に伝達され, 操舵力と釣り合う. 運転者は視覚, 体性感覚, 深部感覚などにより車両の運動を知覚しフィードバック制御を行う.つまり,操舵系フィードバックループを構成 している. 運転者の伝達特性（運転者モデル: $H(j \omega)$ ) は個人差があり, 制御対象の特性や外乱などによっても 変化すること（適応動作）が知られている. そのため, 車両システム全体の伝達関数 $G(j \omega)$ は運転者の負担を 少なく設定することが重要である. 本制御系ループで適度な速応性, 減衰性, 定常特性を持つためには, ゲイン が $0 \mathrm{~dB}$ となるクロスオーバー周波数 $\omega_{c}$ 近傍において，その傾きは $-20 \mathrm{~dB} / \mathrm{dec}$ 程度を適用している. 運転者の伝達 特性 $H(j \omega)$ がむだ時間遅れ $\tau_{e}$ を含むとすると, 開ループ伝達特性は式(1)に示す通り, 積分要素として記述できる (7)-(9) ことが述べられている. 寸なわち閉ループにおいて, ヨーレートなどの偏差が低周波数の領域では, その定 常偏差を低減させる特性となる．また，ノイズなどの高周波数の偏差に対しては，口バストな特性(7)-(9) となる. (図 2(b)）これらは，運転者-自動車系閉ループの安定性においても重要な特性である. 


$$
H(j \omega) G(j \omega)=\omega_{c} \frac{e^{-\tau_{e} j \omega}}{j \omega}
$$

これを前提に $\mathrm{H}(\mathrm{j} \omega)$ のばらつきや変化を考慮すると, 目標の機械モデル $\left(G(j \omega)=G_{s}(j \omega) \cdot G_{c}(j \omega)\right)$ は単一に定め られない. そこで $\mathrm{G}(\mathrm{j} \omega)$ を数值解析で導出するために, 代表的な運転者特性を適用し, それに対する目標の $G(j \omega)$ を求める. 車両設計における具体的な物理量の一例として, 入力トルク $T_{h}$ に対寸る出力ヨーレート $\gamma$ の目標特性 を, 式（2）のように定義する．この時，シャシー側特性 $G_{c}(j \omega)$ を決めることができれば，ステアリングの目標 特性 $G_{s}(j \omega)$ は式（3）のとおり定量的に導出できる.

$$
\begin{aligned}
& \gamma(j \omega)=G(j \omega) \cdot T_{h}(j \omega) \\
& G_{s}(j \omega)=\frac{G(j \omega)}{G_{c}(j \omega)}
\end{aligned}
$$

\section{$4 \cdot 2$ ステアリング詳細モデル}

4.1 節で得られる目標特性 $G_{s}(j \omega)$ を用いて操舵感設計を行うためには， $G_{s}(j \omega)$ の特性とステアリングシステムの 各要素部品の特性との相関が既知である必要がある.

そのため, ステアリングシステムの物理特性をできる限り厳密に表現したモデリングが必要となる.

図 3 にコラム軸アシスト式パワーステアリングシステム（C-EPS）をモデル化した例を示す．図 3 内の(1)（9) はステアリングシステムにおける要素部品ブロックである。ここで $I, M$ は慣性， $K, R, C$ はそれぞれ，弾性， 摩擦, 粘性を示す. $T, \theta, F, X$ はそれぞれトルク, 変位角, 力, 変位量を示す. また, 添字 $h$ はステアリング ホィール部，el は上部衝撃吸収機構部， $c 1$ は上部コラム部， $t$ はトーションバー部， $c 2$ は減速機部を含んだ下部 コラム部， $w$ はウォームギヤ部， $m$ はモータ部，e2 は下部衝撃吸収機構部，in は中間シャフト部， $p$ はピニオン シャフト部, $r$ はラックバー部, $r h$ はラックハウジング部, $g$ はラックブーツ部, $r l$ はラック負荷部を示す. $K_{c 2}$,

$K_{r p}$, はそれぞれ減速機とウオームギヤ，ピニオンギヤとラックバーとの噛合い部， $d_{p}$ はピニオンギヤのピッチ 円直径， $K_{m w}$ はウォームギヤとモータ軸の接合部の弾性を示す. 図に明示していない要素部品の特性は以下の ように定義する.コラムハウジングの取り付け部の弾性, 中間シャフトにある自在継手の位相に応じたトルク 変動による影響は $R_{c i}, C_{c i}(i=1,2), R_{i n}, C_{i n}$ にて考慮している. $R_{r}, C_{r}$ はラックバーとラックハウジングとの 摩擦であり，ヨークシートの押し付け力およびブッシュの摺動力を考慮している. ラック負荷部の弾性 $K_{r l}$ は ラックストローク $X_{r}$ に応じたタイヤからの反力を模擬している.

本モデルは図 3 に示した各要素部品（1)～(9)）ごとに式（4）～（12）で記述される. 式（4）～（10）は回転 軸方向に対して, 式 (11), (12) はラックバーのストローク方向に対しての運動方程式である.

$$
\begin{gathered}
I_{h} \ddot{\theta}_{h}=T_{h}-C_{h}\left(\dot{\theta}_{h}\right)-R_{h}\left(\theta_{h}\right)-K_{e 1}\left(\theta_{c 1}, \theta_{h}\right) \\
I_{c 1} \ddot{\theta}_{c 1}=-C_{c 1}\left(\dot{\theta}_{c 1}\right)-R_{c 1}\left(\theta_{c 1}\right)-K_{t}\left(\theta_{c 1}, \theta_{c 2}\right)-K_{e 1}\left(\theta_{c 1}, \theta_{h}\right) \\
\left(I_{c 2}+I_{r g}\right) \ddot{\theta}_{c 2}=-C_{c 2}\left(\dot{\theta}_{c 2}\right)-R_{c 2}\left(\theta_{c 2}\right)-K_{e 2}\left(\theta_{c 2}, \theta_{i n}\right)-K_{w}\left(\theta_{c 2}, \theta_{w}\right)+K_{t}\left(\theta_{c 1}, \theta_{c 2}\right) \\
I_{w} \ddot{\theta}_{w}=-C_{w}\left(\dot{\theta}_{w}\right)-R_{w}\left(\theta_{w}\right)-K_{m w}\left(\theta_{w}, \theta_{m}\right)+K_{w}\left(\theta_{c 2}, \theta_{w}\right) \\
I_{m} \ddot{\theta}_{m}=T_{m}-C_{m}\left(\dot{\theta}_{m}\right)-R_{m}\left(\theta_{m}\right)+K_{m w}\left(\theta_{w}, \theta_{m}\right)
\end{gathered}
$$




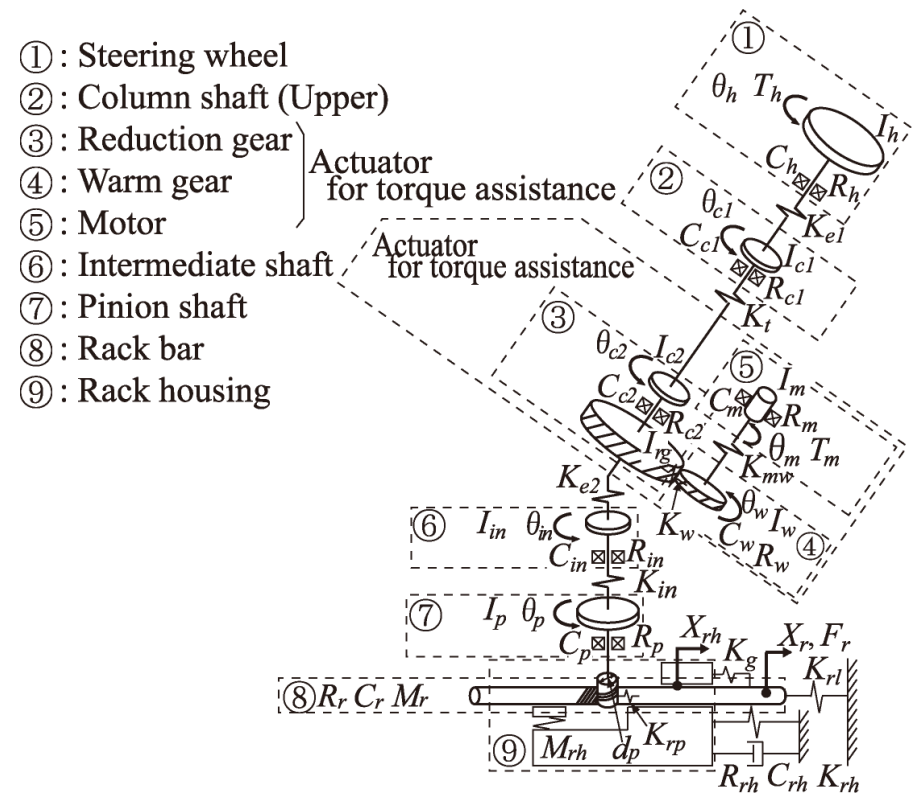

Fig.3 Steering model (C-EPS)

$$
\begin{gathered}
I_{i n} \ddot{\theta}_{i n}=-C_{i n}\left(\dot{\theta}_{i n}\right)-R_{i n}\left(\theta_{i n}\right)-K_{i n}\left(\theta_{i n}, \theta_{p}\right)+K_{e 2}\left(\theta_{c 2}, \theta_{i n}\right) \\
I_{p} \ddot{\theta}_{p}=-C_{p}\left(\dot{\theta}_{p}\right)-R_{p}\left(\theta_{p}\right)-K_{r p}\left(\theta_{p}, X_{r}, d_{p}\right)+K_{i n}\left(\theta_{i n}, \theta_{p}\right) \\
M_{r} \ddot{X}_{r}=-C_{r}\left(\dot{X}_{r}, \dot{X}_{r h}\right)-R_{r}\left(X_{r}, X_{r h}\right)-R_{r s}\left(X_{r}, X_{r h}\right)-K_{g}\left(X_{r}, X_{r h}\right)-K_{r l}\left(X_{r}\right)+K_{r p}\left(\theta_{p}, X_{r}, d_{p}\right) \\
M_{r h} \ddot{X}_{r h}=-C_{r h}\left(\dot{X}_{r h}, \dot{X}_{r}\right)+R_{r}\left(X_{r h}, X_{r}\right)-R_{r h}\left(X_{r h}\right)-K_{r h}\left(X_{r h}\right)+K_{g}\left(X_{r}, X_{r h}\right)
\end{gathered}
$$

\section{$4 \cdot 3$ 詳細モデルにおける非線形特性}

近年 EPS を活用して, 狙いの操舵感を実現することが一般的に行われている. モータトルク $T_{m}$ は, トルク センサにより検出された検出トルク值 $T_{s}$ に応じたモータ電流 $i$ (図 5) をコントロールユニットで算出し, 電子制 御で決定される. これを利用して, アシストトルクの制御により, 操舵力特性を調整している. 理論上, モータトルク $T_{m}$ はモータ電流 $i$ に比例する. (式 13)

$$
T_{m}=K_{m} i
$$

しかし実際には摩擦などの影響により，モータ動き出しのトルクが小さい領域では，図 4 に示すような非線形の 特性を示寸．また，操舵速度などの条件によっては，上記モータ特性が変化する場合があり，それを制御によっ て補償することがある，今回はその条件に該当しないため，その変化及び補償制御についてはモデルから除外し ている.

また, トルクセンサについても, 理論上はトルクが 0 から検出最大值までトルクに比例した電圧を出力する. ところが実際の製品では，トルクが検出されてもモータに電流を流さない領域（不感帯）を設けている（図 5). 不感帯を設定していないとノイズ等によるアシスト方向の反転の恐れがあり, 一方で不感帯が大きいと, 分解能 の限界により急激なアシストトルク増加の恐れがある. したがって, 適正量の不感帯を設けているが，これも非 線形特性の要因の一つである. 


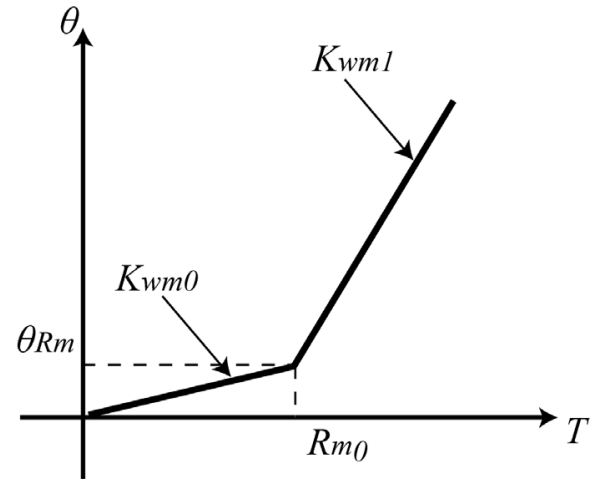

Fig.4 Characteristic of connection part

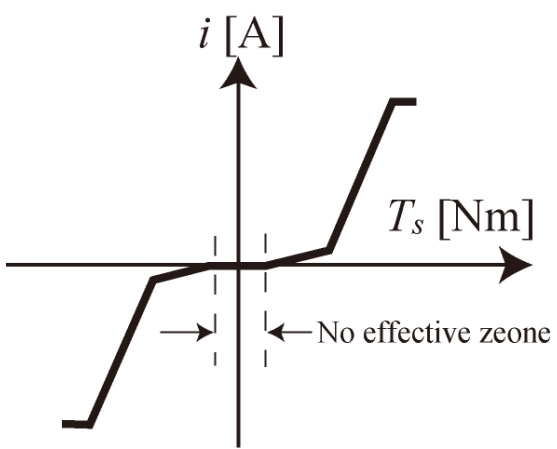

Fig.5 Motor current control diagram

図 6 は，一般的なトルク一角度特性の例である. EPS による電子制御は，モータやトルクセンサ線形特性を 示す $3 \mathrm{Nm}$ を超える領域で特に有効である。しかし，運転時間の大半を占めるため，操舵感として重要となる 直進状態からの切り出しでは，上記非線形特性の影響を大きく受ける。このため，様々な要因による非線形特性 を詳細モデルに織り込み，その影響を適切に評価する必要がある.

そのためモデルを記述する各式中の $K, R, C$ は非線形特性として扱っている．紙面の都合で詳細については 割愛するが，一例として式（8）中での各要素特性を以下に示す.

モータ部粘性要素 ;

$$
C_{m}\left(\dot{\theta}_{m}\right)=C_{m}
$$

モータ部摩擦要素 ;

$$
\begin{array}{r}
R_{m}\left(\theta_{m}\right)=T_{m} \quad\left(a t T_{m} \leq R_{m 0}\right) \\
R_{m}\left(\theta_{m}\right)=R_{m 0} \quad\left(a t T_{m} \geq R_{m 0}\right)
\end{array}
$$

ウォームギヤとモータ軸の接合部の弾性要素 ;

$$
\begin{aligned}
& K_{m w}\left(\theta_{w}, \theta_{m}\right)=K_{m w 0}=R_{m o} / \theta_{R m}\left(a t T_{m} \leq R_{m 0}\right) \\
& K_{m w}\left(\theta_{w}, \theta_{m}\right)=K_{m w 1}=R_{m 0}\left(a t T_{m} \geq R_{m 0}\right)
\end{aligned}
$$

本式における $\theta_{R m}$ は, モータ単体での $T-\theta$ 特性計測時の折れ点の角度を示す (図 4). モ一タの電磁気的, 機械 的なトルク変動は $R_{m}, C_{m}$ として考慮できる.

このように式中の $K, R, C$ の非線形特性は, 摩擦要素の非線形特性のモデル化手法 ${ }^{(6)}$ (10) などに加え, 実測結 果を元に決定した．それぞれの特性は，各部の変位，変位速度の関数で表される.これにより，例えば図 6 にお けるトルク $3 \mathrm{Nm}$ 以下のステアリング切り出し領域における操舵力特性を正確に解析することを狙いとした. 図 7 にその実測結果の一例を示す。操舵卜ルクが約 $2 \mathrm{Nm}$ に達するまでは，ヨーレートの発生がほとんどなく，2Nm 以 上でヨーレートの増加勾配が急に大きくなる. また操舵卜ルク $2.8 \mathrm{Nm}$ 付近において，ヨーレートの増加勾配が減 少する.この特性により, 官能評価として「ヨー運動が滑らかに発生しない」との結果が得られている. 


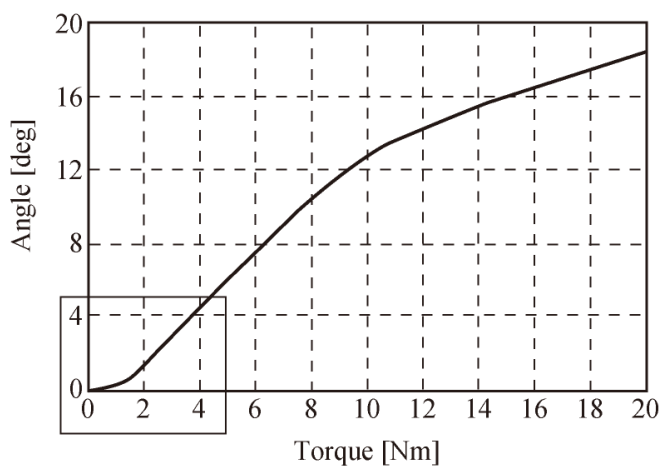

Fig.6 Steering wheel torque - wheel angle diagram

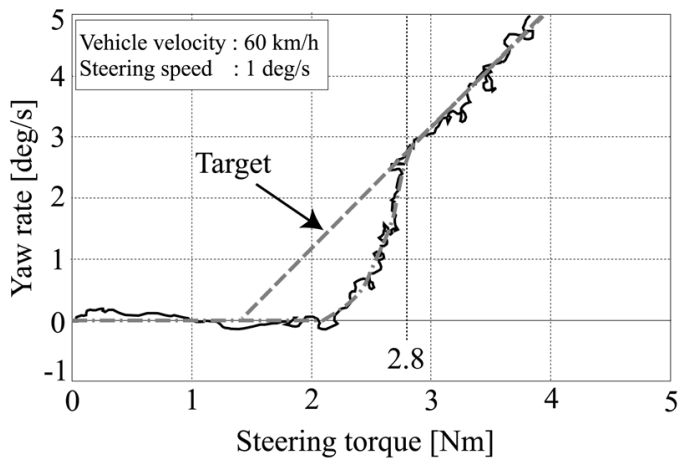

Fig.7 Steering torque - yaw rate

\section{$4 \cdot 4$ 要素部品の目標性能導出}

式（4）〜（12）を線形近似した場合の伝達関数 $G_{a}$ は式（19）と記述できる.

$$
G_{a}(s)=\frac{b_{m} s^{m}+\cdots+b_{1} s+b_{0}}{a_{n} s^{n}+\cdots+a_{1} s+a_{0}} \quad(m, n=1,2, \cdots)
$$

係数 $a_{i}, b_{i}$ は各要素部品のパラメータから定まる. 次に, 4.1 節に示した操舵感の設計目標となるモデル特性 $G_{s}$ と本モデルの伝達関数 $G_{a}$ とを比較する. これより, 各要素部品設計に必要なパラメータの目標值が定量的に 求まる. また, 時間応答特性に対して各要素部品のパラメータの目標值を定量的に定めることも重要である. 例えば, 非常に小さい操舵速度と操舵量の場合は, 式（3）～（11）における慣性項と粘性項を除外できる. この時, 運転者による入力であるステアリングホィールトルク $T_{h}$ と, 車両側への出力であるラックストローク $X_{r}$ との関係は式（20）のとおり記述できる.

$$
X_{r}(t)=\frac{1}{K_{r l}}\left\{T_{h}(t)+T_{m}(t)-\sum_{R_{i}}\left(\theta_{i}, t\right)\right\}
$$

これにより，この入出力関係から目標となる各要素のパラメータが定量的に求められる.

\section{$4 \cdot 5$ 操舵感向上のための伝達系要素部品設計プロセス}

以上を踏まえ, 操舵性能向上のためのステアリング伝達系要素部品の伝達特性を最適化する設計プロセスを 整理する.

（1）操舵感官能評価を操舵性能の物理特性モデルとして扱い，操舵システムの目標性能を定量的に設定する.

（2）車両サブシステムの伝達特性が，上記システム性能に与える影響を評価する.

（3）各要素に最適に割り付けられた伝達特性に関する物理量を，部品ごとの設計目標値として決定する.

（4）車両ごとの設計制約条件を考慮し，上記の目標值の採否を判断する.

上記（1）に関しては，3.2 節で述べた多変量解析手法などを用いて明らかにすることができる．上記（2）につ いてはステアリング側要素特性とシャシー側要素特性の比較を例に 5 章で述べる。（3）についてはステアリング 系構成要素の伝達特性解析を例に 6 章で述べる.

\section{5. 車両サブシステム伝達特性の影響評価}

ステアリングシステム厳密モデルと車両モデルを用いて, 車両サブシステム特性が操舵システムの性能に 与える影響を評価する. 

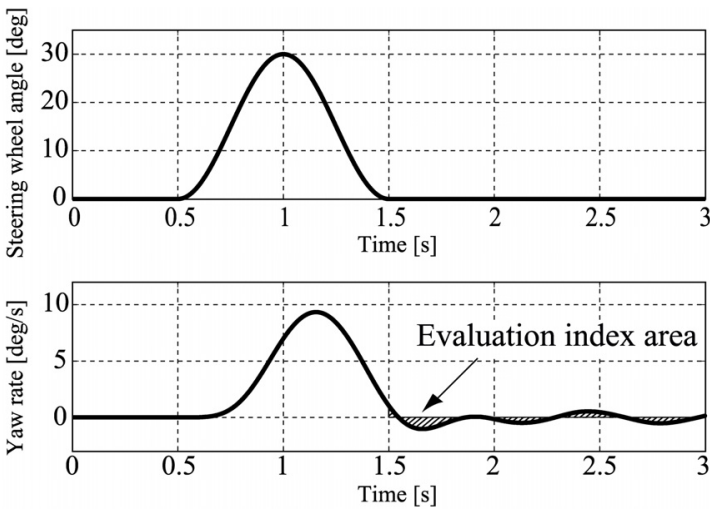

Fig.8 Input conditions and evaluation index

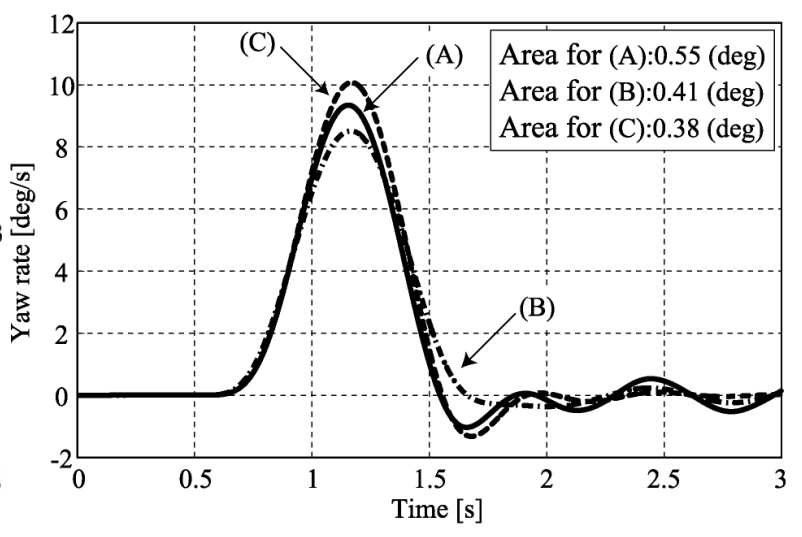

Fig.9 Comparison of yaw rate

例として, 旋回から直進への移行時の「安定感」の向上を示す．この場合，操舵入力終了時からのヨーレート の絶対值の時間積分值が「安定感」の指標として提案(11)されている.

評価試験結果の一例を図 8 に示す.上段は $1 \mathrm{~Hz}$ 正弦波形状の入力ステアリングホィール角を，下段はこの時の 車両のヨーレートを示している．操舵終了時からヨーレートが収束するまでの時間積分值（同図の斜線部）は $0.55 \mathrm{deg}$ である.

ヨーレートの動的特性に影響を及ぼす車両システム,および要素部品を要因分析によって抽出した. 主な要素 部品特性を表 4 に示す. これらの要素によるヨーレート積分值への影響を定量化するため数值解析を行った. ステアリングモデルおよび車両モデルは,一般的な四輪モデル(12)を採用し, 表 4 に示寸要素部品特性を考慮した.

ステアリング側要素特性（表 4-i ）の変更によるヨーレート収束性の改善策として，タイヤに近いラックバー 部の粘性 $C_{r}$ を増し, 中間シャフトの弾性 $K_{i}$ を増した。この解析結果を図 9 （B）に示す．また，シャシー側要素 特性 (表 4- ii) の変更による改善として, ロールに伴うトー角変化を減らした. この解析結果を図 9 (C) に示寸.

評価指標であるヨーレート積分值は, 改善前（図 9 (A)）が 0.55deg であったのに対して，(B) では $0.41 \mathrm{deg}$, (C) の場合では 0.38deg であった。 これは, ステアリング側とシャシー側, いずれの構成要素の特性変更に よっても,「安定感」を改善できることを示している.

Table 4 Model parameters

\begin{tabular}{l|l}
\hline \multicolumn{1}{c|}{$\begin{array}{c}\text { Vehicle } \\
\text { Subsystem }\end{array}$} & \multicolumn{1}{c}{ Elemental characteristic } \\
\hline (i) Steering & Refer fig.3 \\
\hline & $\begin{array}{l}\text { Roll (Inertia, Viscous, Stiffness) } \\
\text { Pitch (Inertia, Viscous, Stiffness) } \\
\text { Change of load } \\
\text { Change of toe angle with suspension stroke } \\
\text { (ii) Chassis }\end{array}$ \\
\hline (iii) Tire & $\begin{array}{l}\text { Compliance-steer characteristic } \\
\text { Cameel alignment }\end{array}$ \\
\hline (iv) Vehicle & $\begin{array}{l}\text { Front axle load, Rear axle load } \\
\text { Moment of inertia } \\
\text { Position of gravity center (height/longitudinal/lateral) } \\
\text { Wheel base } \\
\text { Track } \\
\text { Stiffness of body }\end{array}$ \\
\hline v) Road surface & Shape (slant, slope) \\
\hline
\end{tabular}


しかし，ステアリング側要素特性を変更した（B）の場合にはヨーレートが 0 になる時間が操舵入力の終了時 に対して遅れている，このことから，車両応答が悪化したと評価される可能性が大きい.

本事例より，ステアリングシステム性能の物理特性モデリングを導入することで，車両サブシステムの伝達 特性が操舵感に与える影響を正確に評価できることがわかる.このことから, 物理特性パラメータを変更するこ とによる背反事象をも考慮した最適な改善方策を決定できる.

\section{6. 伝達系要素部品の伝達特性最適化}

ステアリングシステムの厳密モデルを用いて, ステアリング伝達系要素に割り付けられた伝達特性を表す物理 量を最適化する.

\section{$6 \cdot 1$ 要素部品の目標特性}

ここでは高速走行時の直進性を保つための微小修正操舵のしやすさを向上する場合の特性モデルを例に示す.

図 6 に示寸，操舵トルク 3 $\mathrm{Nm}$ 以下の領域における特性について，検討を行った.

高速走行時には, 運転者は目標とする微小舵角修正を,操舵力を僅かに増減することで行っている. 微小操舵力 入力に対して, 高速走行に必要な微小なステアリングホィール角変化 $\Delta \theta_{h}$ と, 期待する車両挙動変化 $\Delta \gamma$ の関係を フィードバックして操作している. 車両挙動変化 $\Delta y$ を適確にフィードバックするには, 視覚などにより フィードバックされる $\Delta \gamma$ に加え, ラック軸力 $\Delta F_{r}$ が適正值でなければならないことは, 4.1 節で示したとおりで ある. 本条件における入力トルク $T_{h}$ に応じた $\Delta \theta_{h}$ および $\Delta F_{r}$ の定量的な目標特性值を次で定義する.

目標指標 $\mathrm{A}$ ：運転者が管理できる微小入力である $T_{h}$ が $1 \mathrm{Nm}$

における $\Delta \theta_{h}$ が $0.7 \mathrm{deg}^{(13)}$. (図 11 の点 $\mathrm{A}$ )

目標指標 $\mathrm{B}$ ：運転者が管理できる微小入力である $T_{h}$ が $1 \mathrm{Nm}$ における $\Delta F_{r}$ が $4 \mathrm{~N}$. (図 11 の点 $\mathrm{B}$ )

\section{$6 \cdot 2$ モデルを用いた解析結果}

C-EPS（図 3）とピニオン軸アシスト式パワーステアリングシステム（P-EPS）の場合について, 各要素の伝達 特性に関わる物理量を, 部品ごとの設計目標值として決定する.P-EPS の解析モデルは図10に示すとおりである. C-EPS モデルと異なる点はアシストアクチュエータ部 (3)～(5))の位置のみであるので, 詳細な説明は省略する.

システムにおいて $T_{h}$ に対寸る $\theta_{h}$, および $T_{h}$ に対寸る $F_{r}$ の解析結果をそれぞれ図 11,12 に示寸。 これらより, 両システムは共に指標 $\mathrm{A}$ および $\mathrm{B}$ を満足していないことが分かる. また, 各要素部品の配置の違いによって, 伝達特性が異なり, P-EPS の方が目標特性值に近いことが分かる.

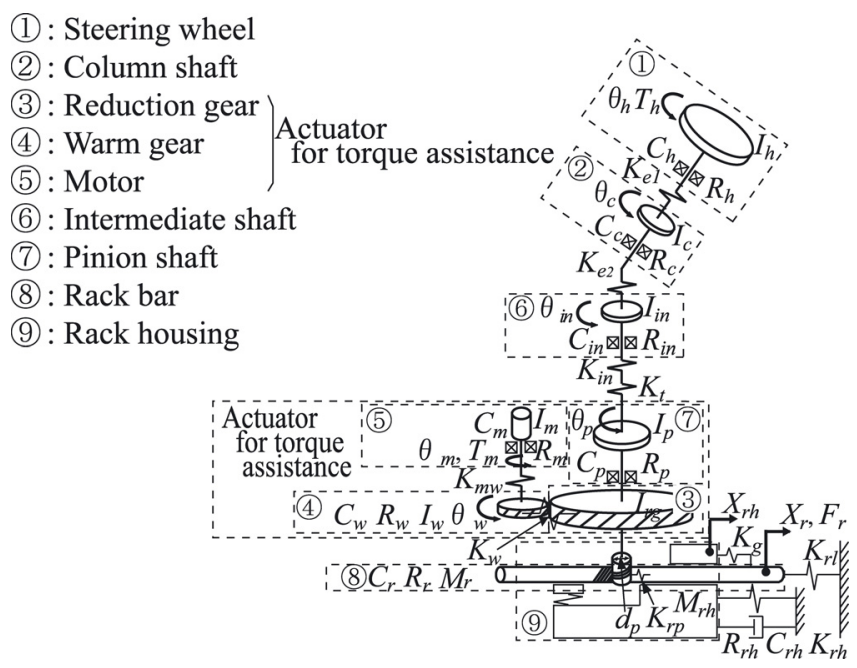

Fig.10 Steering model (P-EPS) 


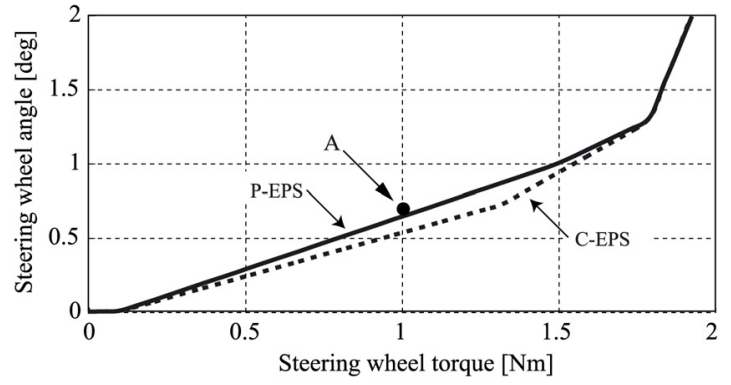

Fig.11 Steering wheel torque - wheel angle diagram

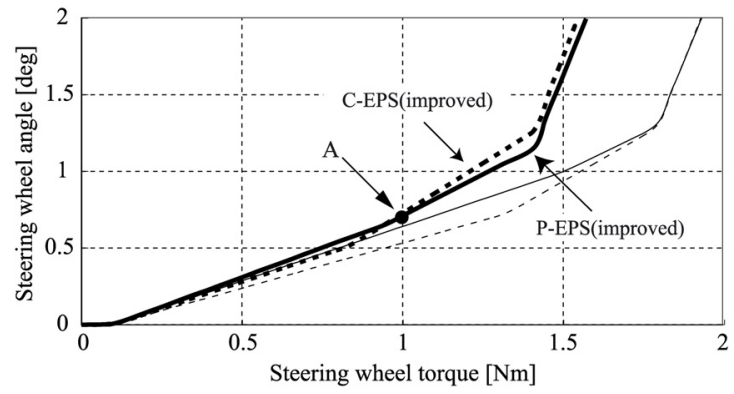

Fig.13 Steering wheel torque - wheel angle diagram

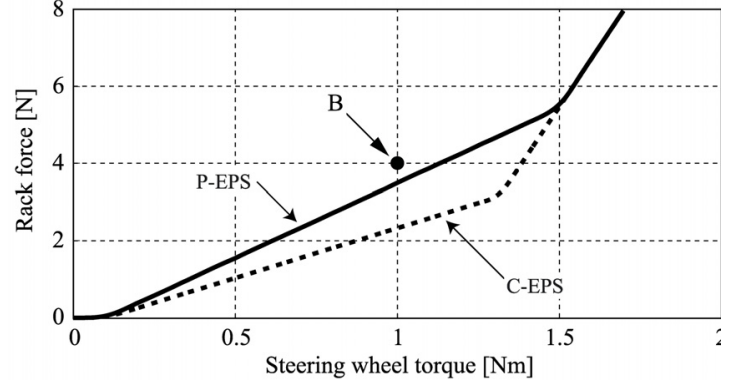

Fig.12 Steering wheel torque - rack force diagram

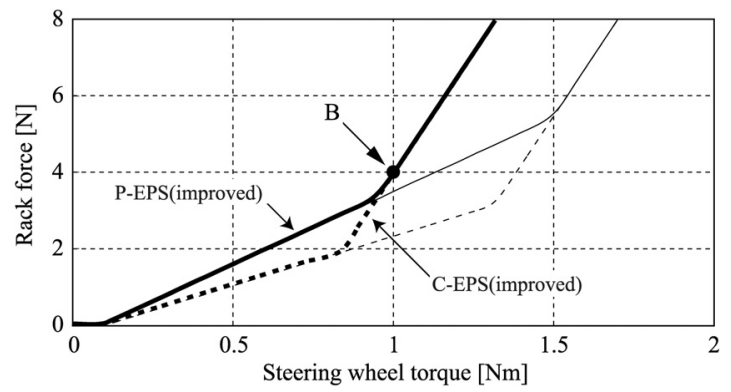

Fig.14 Steering wheel torque - rack force diagram

\section{$6 \cdot 3$ 解析による要素部品特性の決定}

両システムで目標指標を達成するための設計事例を示す．図 11，12 において，各変曲点およびその傾きは トルクが小さい方から順に入力側からの要素部品の配置と呼応し, C-EPS（図 3）とピニオン軸アシスト式パワー ステアリングシステム（P-EPS）の場合について，各要素の伝達特性に関わる物理量を，部品ごとの設計目標值 として決定する. システムの主な摩擦 $R_{h}, R_{w}, R_{m}, R_{r}$ および弾性 $K_{t}, K_{i n}, K_{r p}$ の特性を示している. C-EPS では 弾性 $K_{t}$ を変更前に比べ約 30\%低減することで指標 $\mathrm{A}$ を満足した（図 13）.そのためには部品強度や基本設計, さらには製造工程など, 様々な設計変更が必要となる.一方 P-EPS を採用すると $K_{t}, K_{i n}$ を約 $5 \%$ 低減すれば良く, C-EPS と比べて実現が容易であることがわかる. また,C-EPS, P-EPS 共にウォーム部およびモータ部の摩擦 $\left(R_{w}\right.$, $R_{m}$ ）を 40\%低減することで指標 B を満足した（図 14）。しかし，本部位のみの変更は現実的には困難であり， 他の部位の要素部品による改善も必要となる. 詳細は次報以降で述べるが，切り出しに加えて，路面からの ラック軸力への入力 $F_{r}$ に対する伝達特性も検討寸る必要がある. この場合, ドライバーへの出力として, ステア リングホィール角 $\theta_{h}$ およびトルク $T_{h}$ への伝達特性をステアリングシステム内で最適化しなければならない. C-EPS と P-EPS では，要素部品の配置の違いによりこれらの伝達特性が異なってくる.

以上のように, 操舵性能を司るステアリング系の物理特性モデリングを導入することで, 要素部品の適正配置 やシステムの伝達特性を定量的に設計することができる.

\section{7. まとめ}

（1）操舵感向上を目的としたステアリング系の伝達要素の伝達特性を最適化する手法を示した.

（2）車両サブシステムの伝達特性が，上記特性に与える影響を定量的に評価する手法を示した.

(3) 各要素に最適に割り付けられた伝達特性に影響を与える物理量を, 部品ごとの設計目標值として決定する 手法を示した. 


\section{8. おわりに}

多岐に渡る操舵感を同時に最適化するためには, 各要素部品の伝達特性を適切に割り付ける必要がある. しか し, 複雑なシステムの中で, それらの要素性能を一義的に定めることはこれまで取り組まれていなかった，そこ で目標とする操舵感に合わせて各要素部品の伝達特性を定量的物理量で表わし, それらを適切に割り付けること で，システム性能を最適化することに取り組んだ. C-EPS とP-EPS の性能差を例に取り，システム性能設計から 要素性能割り付けを実現するための手法を初めて明らかにした，第 2 報以降で，実際の操舵感ベンチマーク結果 から，理想とされる操舵感を実現する要素部品の定量的設計手法の適用例などを，引き続き紹介していく．これ らを通じて，ステアリング系伝達要素の設計プロセスを各物理量に応じて具体化する手法を明らかにする.

\section{文献}

(1) 中野史郎，“自動車の操作系要素技術”，自動車技術会シンポジウムテキスト,(2004)

(2) 横小路泰義, 吉川恒夫, “マスタ・スレーブ型遠隔操縦システムの操作性”, 計測自動制御学会論文集, Vol.26, No.5 (1990), pp. 572-579

(3) George E. Cooper, Robert P. Harper, Jr., "THE USE OF PILOT RATING IN THEEVALUATION OF AIRCRAFT HANDLING QUALITIES”, NASA TECHICAL NOTE, D-5153 (1969)

（4）木原三津夫，“感性に基づく車両運動性能評価”，ISS 産業科学システムズシンポジウムテキスト

(5) 佐藤博文, 原口哲之理, 大沢洋, “操舵感に関わる操舵応答特性の考察” , 自動車技術, Vol.44, No.3 (1990), pp. 52-58

(6) Ikuo Kushiro, Singo Koumura, Hiroyuki Kawai, “A New Approach in the StudyOn-Center Handling”, AVEC2008, pp.184-189

(7) DUANE T. McRUER, R. WADE ALLEN, DAVID H. WEIR, RICHARD H. KLEIN, "New results in driver steering control models", HUMAN FACTORS, Vol.19, No.4(1977), pp.381-397

（8）藤岡健彦，堀内伸一郎，“自動車技術基礎講座第 4 章運動性能”，自動車技術, Vol.54, No.11(2000), pp. 82-87

(9) 永井正夫，“マン・マシン・システムの理論” , 自動車技術, Vol.39, No.5 (1985), pp. 486-492

(10) Neureder Uwe, "Modeling and simulation of the steering system to investigate steering nibble", Automobiltech techniche zeitschrift, vol.103, No.3 (2001), pp. 216-224

(11) 河内宏司, 前川暁夫, 平野和夫, 中島志郎, “車両操縦安定性の定量評価技術の開発”, SEI テクニカルレビュー, Vol.165, No.9 (2004)

（12）安部正人，車両運動の基礎 自動車の運動と制御，第二版 (1992)，p. 49-104，山海堂.

(13) 山田大介, 畔柳洋, 小野英一, 久代育生, 許斐謙二, 佐藤伸介, “ステアリングシミュレータを用いたオンセンター フィールの解析”，自動車技術会 学術講演会前刷集，No.59-8(2008), pp. 5-10 